\title{
WATER QUALITY IN THE HUDSON RIVER BASIN: WORKING TOGETHER TO SOLVE THE PUZZLE
}

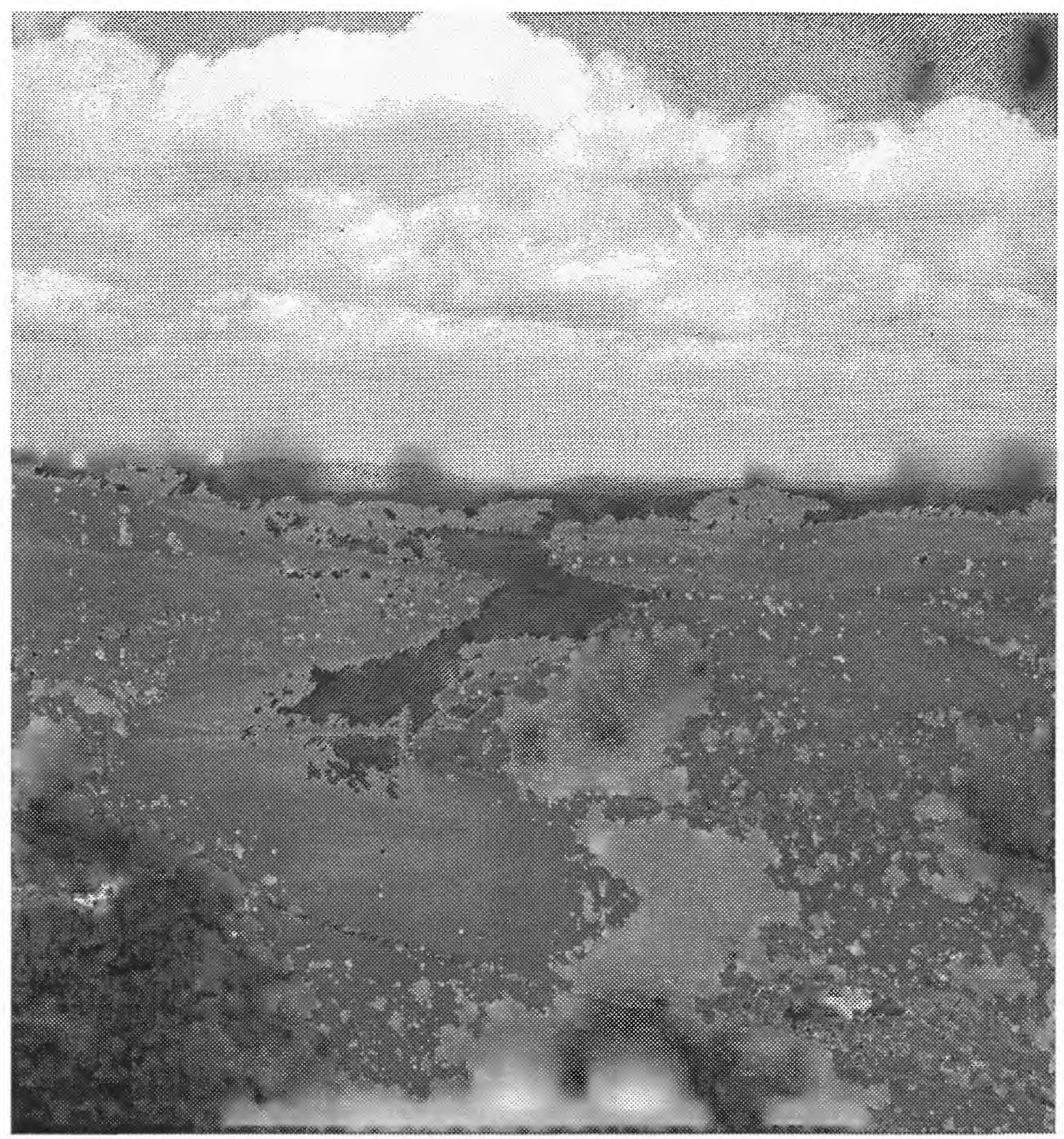

\section{U.S. GEOLOGICAL SURVEY}

NATIONAL WATER-QUALITY

ASSESSMENT PROGRAM

SYMPOSIUM APRIL 1994

Open-File Report 94-90

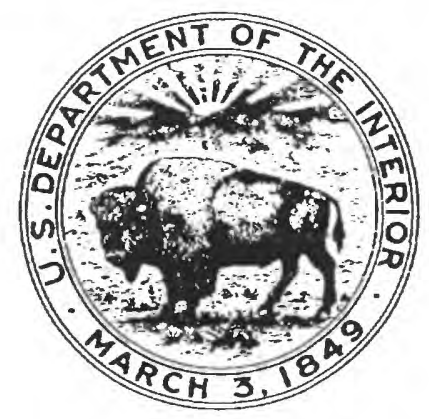




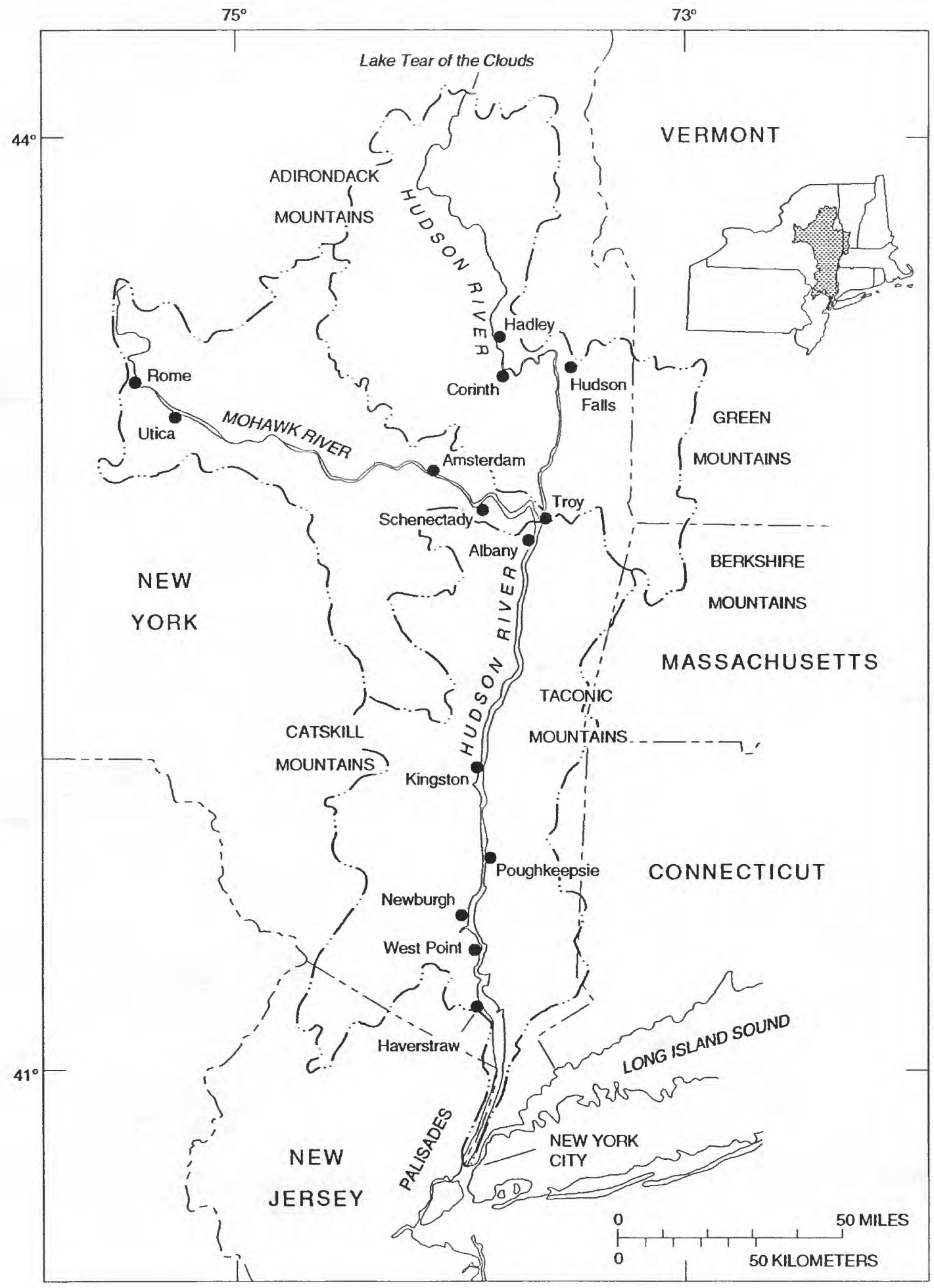

Figure 1. --Drainage divides of the Mohawk and upper and lower Hudson River basins (modified from Freeman, 1991).

Cover Photo: Northward view of Hudson River with Bear Mountain Bridge. Courtesy of John George, New York State Department of Environmental Conservation. 


\section{UNDERSTANDING WATER-QUALITY IN THE HUDSON RIVER BASIN: \\ WORKING 'TOGETHER TO SOLVE THE PUZZLE \\ by Karen $R$. Murray and Ward $O$. Freeman}

Understanding water quality is like working on a jigsaw puzzle in which each piece of information contributes to the final picture. Chemical, physical, and biological conditions and their interactions need to be described, and effects of farming practices, urbanization, water use, and other human activities need to be determined. The National WaterQuality Assessment (NAWQA) Program of the U.S. Geological Survey provides some of this information for the Hudson River Basin by conducting field investigations that include stream-and ground-water chemistry, fish and insect ecology, and sediment-contamination surveys. Because no single program can provide all the pieces to this puzzle, NAWQA personnel share data, coordinate sampling, and discuss findings with scientists and resource managers from universities, State and local governments, and private groups to help complete the picture. NAWQA scientists also participate in high-school education programs to help foster an interest in water-resource investigation so that some of these young people may contribute to future work on the "water-quality puzzle." Some examples of how NAWQA scientists work with others are summarized below.

\section{Local guidance through liaison committee}

NAWQA project personnel work with a liaison committee of government researchers and managers, university scientists, and others in many stages of the project, from design and data collection to interpretation of results. Early in the design of the Hudson River Basin study, the liaison committee identified locally critical water-quality issues, including nonpoint-source pollution of rivers and streams from urban and agricultural runoff; contamination of suspended sediment by metals; contamination of the Hudson River's bottom sediments, water, and the food web by polychlorinated biphenyls (PCB's); and the lack of information on groundwater quality in the basin. They also suggested locations for stream and aquifer surveys. Periodic liaison-committee meetings provide a forum for informing water-resource managers and scientists of NAWQA's findings and discussing water-quality issues. For example, a recent liaison meeting included presentation of preliminary results from (1) a survey of contaminants in fish tissue, (2) a survey of water chemistry in 42 streams, and (3) a study of historical trends in stream and ground-water quality. The meeting also included presentation of research being done in the basin by two other agencies.

\section{Teaming up with New York State}

NAWQA personnel coordinate data-collection efforts with several State programs to enhance acquisition and use of water-quality information. One example is coordination between the NAWQA program and the Rotating Intensive Basin Survey (RIBS) of New York State Department of Environmental Conservation. The objectives of the NAWQA program and RIBS are complementary--NAWQA's focus is nonpoint-source pollution such as urban and agricultural runoff, whereas RIBS' focus is point-source pollution such as effluent from sewage-treatment plants. Scientists from NAWQA and RIBS frequently cooperate to collect samples and share data. "Teaming up" this way allows both programs to obtain more information on a greater number of streams than either program could afford to obtain on its own, and may increase our knowledge of the relative contribution of point-source and nonpoint-source pollution to water-quality conditions in the Hudson River Basin.

\section{Training future scientists}

NAWQA scientists help support environmental education in 13 local high schools that participate in the River Watch Network. River Watch Incorporated and other private and public sponsors provide training for teachers, technical advice, and equipment to give students hands-on experience in stream measurements, chemical sampling, and identification of aquatic insects. Sharon Behar, Education Coordinator for River Watch said, "The success of this pilot project exceeded our expectations in terms of the numbers of students involved, sustainability of the program after the grant period, and school-community connections."

\section{Modelling watersheds}

Excessive amounts of carbon. nitrogen, and phosphorus in streams can cause water-quality problems such as nuisance algal blooms, oxygen depletion, and damage to fisheries. Nutrients in runoff from urban and agricultural lands into lakes and rivers commands national attention and is also of concern in the Hudson River Basin. Dr. Robert Howarth, project director of the Watershed Modelling Program at Comell University (Ithaca, New York) states "To fully understand the effect of land use on the export of sediments and chemical constituents to the Hudson River will require data from actual watersheds." 
Dr. Howarth and his team use field data, provided by NAWQA scientists, to develop a computer model of the quantities of sediments, nutrients, and organic material discharged to the Hudson River from watersheds with various land-use and geologic characteristics. The use of NAWQA data in this model could vastly expand the NAWQA program's spatial coverage within the Hudson River Basin.

\section{Researching hazardous-metals transport}

Contamination of rivers and streans by metals is a major water-quality concern, according to the Hudson NAWQA liaison committee. For example, the world's highest known levels of contamination by elemental cadmium and nickel have been found in sediments of Foundry Cove, an Environmental Protection Agency Superfund site on the lower Hudson River (near West Point). High concentrations of these metals can be toxic to fish, other wildlife, and humans. Dr. Ronald Gibb, of the University of Delaware at Lewes, is exploring the way in which waterborne sediment particles transport these and other metals into the Hudson River. NAWQA scientists are collecting suspended-sediment samples for Dr. Gibb's study. This cooperation between researchers at the University of Delaware and NAWQA personnel will help explain how metals and other contaminants such as PCBs are transported in the river.

\section{National Geographic Society supports NAWQA-related university research}

Two studies on water quality in the Hudson River Basin are currently (1994) funded through a memorandum of agreement between NAWQA and the National Geographic Society. Dr. Richard Bopp, of Rensselaer Polytechnic Institute (Troy, NY), was awarded a grant to conduct a basinwide study involving age determination of contaminated bottom sediments in the Hudson River Basin. Dr. Bopp states "One of the best means to characterize major sources of contaminants and to reveal historical trends in contaminant levels is through the use of dated sediment cores."

The second National Geographic Society grant was awarded to Dr. Rebecca Schneider of Comell University, to investigate the effect of wetlands on Hudson River water quality. Dr. Schneider states "Wetlands play a major role in trapping sediments, decreasing nutrient concentrations, storing floodwaters, and mediating the effects of other factors on water quality in a stream system."

\section{PCB findings lead to State followup}

Polychlorinated biphenyls (PCB's) can bioaccumulate to high levels in fish, birds, and mammals. They are known to produce toxic effects in these organisms and may cause cancer in humans. PCB's were once widely used in electrical transformers and hydraulic fluids and for many other industrial applications. Although use and production of PCB's have been banned for many years, these contaminants are highly persistent in the environment.

PCB's were one of the more common symthetic organochlorine compounds detected in fish specimens in a 1992 NAWQA survey of 13 sites on streams and rivers in the Hudson River Basin. PCB concentrations in fish tissue corresponded broadly with the degree of urbanization and industrialization in the watershed.

Highest concentrations of PCB's were found in fish from the Hudson River and its largest tributary, the Mohawk River. NAWQA results for the Hudson River correspond with levels previously documented by the New York State Department of Environmental Conservation and do not indicate any new conditions. PCB concentrations in whole-body composites of carp (Cyprinus carpio) from the Mohawk River were as high as 33 micrograms per gram (parts per million). These concentrations indicate a need for additional information on conditions and causes of $\mathrm{PCB}$ contamination. After a briefing on NAWQA findings, State scientists have taken steps toward establishing a health advisory for the affected reach of the Mohawk River. They are also planning a followup survey to (1) assess PCB concentrations in game fish and other species, (2) delineate the affected section of river, and (3) investigate possible sources.

Linking of the NAWQA PCB findings with subsequent State followup is a good example of working together to assemble pieces of the puzzle and thereby improve our understanding of water quality in the Hudson River basin.

Additional information can be obtained from:

Chief, Hudson River Basin NAWQA

U.S. Geological Survey

P.O. Box 1669

Albany, N.Y. 12201

(518) $472-3107$ 